\title{
Analysis of the deoxidation process of copper with manganese using a platinum electrode-based sensor prepared by MOCVD( ${ }^{(\cdot)}$
}

\author{
S. González-López*, A. Romero-Serrano*, R. Vargas-García*, B. Zeifert* and A. Cruz-Ramírez*
}

\begin{abstract}
A sensor employing yttria-stabilized zirconia (YSZ) was used to determine the oxygen partial pressure and oxygen content in liquid $\mathrm{Cu}-\mathrm{Mn}$ alloys in the range $1,100^{\circ}$ to $1,300^{\circ} \mathrm{C}$. The $\mathrm{YSZ}$ sensors were coated with platinum electrode films deposited by metal organic chemical vapor deposition (MOCVD) to increase the conductivity of the measuring devices and to decrease their response time. The depth of the Pt film measured was $7 \mu \mathrm{m}$. At 1,200 and $1,300^{\circ} \mathrm{C}$ fair agreement was obtained between the oxygen contents calculated from the measured probe EMF and those obtained by chemical analysis. The deoxidation process of liquid copper using $\mathrm{Mn}, \mathrm{Fe}$ and $\mathrm{P}$ was analyzed by the interaction parameters model which showed that the minimum oxygen content at $1,200^{\circ} \mathrm{C}$ was about 2, 90 and $500 \mathrm{ppm}$, using manganese, iron and phosphorus as deoxidation agents, respectively.
\end{abstract}

\section{Análisis del proceso de desoxidación de cobre con manganeso usando sensores con electrodos base Pt preparados por MOCVD}

\begin{abstract}
Resumen
En este trabajo, se utiliza un sensor de zirconia estabilizada con itria (ZEI) para determinar la presión parcial y el contenido de oxígeno, en aleaciones líquidas Cu-Mn entre 1.100 y $1.300{ }^{\circ} \mathrm{C}$. Los sensores ZEI fueron recubiertos con una película de platino mediante el método de depositación en fase vapor empleando un precursor metal orgánico (MOCVD) con el fin de incrementar la conductividad del sensor y disminuir el tiempo de respuesta. El espesor medido de la película de platino fue de $7 \mu \mathrm{m}$. A las temperaturas de 1.200 y $1.300^{\circ} \mathrm{C}$ se obtuvo buena concordancia entre los contenidos de oxígeno calculados a través de la FEM del sensor y los obtenidos mediante análisis químico. El proceso de desoxidación del cobre empleando manganeso, hierro y fósforo fue analizado mediante el modelo de parámetros de interacción, el cual mostró que el mínimo contenido de oxígeno en equilibrio, a $1.200^{\circ} \mathrm{C}$, fue de, casi 2 , 90 y 500 ppm, respectivamente, usando manganeso, hierroy fósforo como desoxidantes.
\end{abstract}

Palabras clave Desoxidación de cobre; Manganeso; Sensor de oxígeno.

\section{INTRODUCTION}

Ramamoorthy et al. ${ }^{[1]}$ presented the advancement of gas sensor technology, especially the oxygen gas sensors. They stated that solid state potenciometric oxygen sensors typically use an oxygen ion conducting material as electrolyte. Among these, yttria stabilized zirconia has been the material of choice due to its ionic nature and high stability in harsh environments.

Considerable progress has been made in recent years with respect to the thermodynamics of solution of oxygen in dilute liquid copper. From these studies, it is seen that the elements phosphorus, iron and manganese decrease the activity coefficient of oxygen in liquid copper in the order mentioned. Then, $\mathrm{Mn}$ is one of the most efficient deoxidizer element of molten copper. Over the last few years, in situ oxidation state control systems have been installed in working chambers and feeder channels in the copper industry in order to control the properties of the final product. Most of these in-situ techniques are based on the electrochemical determination of the oxygen content in the copper melt by using yttria-stabilized zirconia (YSZ) which is an oxygen ion conductor.

High temperature galvanic cells have become very useful for numerous applications in both fundamental and applied measurements. There are

(•) Trabajo recibido el día 22 de Mayo de 2009 y aceptado en su forma final el día 1 de Diciembre de 2009.

* Metallurgy and Materials Department, IPN-ESIQIE, A. P. 118-431, México D.F. 07051. E-mail: sammetal0525@hotmail.com;romeroipn@hotmail.com;j_vargas_garcia@hotmail.com;bzeifert@yahoo.com; alcruzr@ipn.mx. 
a number of applications where chemical sensors can improve the efficiency and the product quality during the processing of molten metals. Since the development of oxygen-ion conducting electrolytes such as $\mathrm{ZrO}_{2}-\mathrm{Y}_{2} \mathrm{O}_{3}$, the oxygen concentration cells have been extensively used both in laboratories and industries. In metal production technology, these cells have been used to register and control the oxygen potential in metals. Nowadays, high temperature solid electrolyte cells involving oxygen ion conducting electrolytes have become an integral part of copper pyro-refining and continuous casting, since it is possible to control the oxygen level and to predict the amount of other alloying elements.

YSZ sensors have been also successfully used to measure gases in air such as $\mathrm{CO}, \mathrm{SO}_{2}$ and $\mathrm{NO}_{x}$ at relatively low temperatures $\left[600-650^{\circ} \mathrm{C}\right]^{[2]}$. Platinum is widely used as the electrode material in these sensors because of its electrocatalytic nature, which promotes charge transfer reactions at the electrolyte/electrode interface. Usually, porous platinum electrodes are prepared by firing platinum paste at around $900-1,200{ }^{\circ} \mathrm{C}$; however, highly catalytic Pt electrodes can also be prepared by an appropriate deposition technique (sputtering or CVD) on the surface of the solid electrolyte ${ }^{[3]}$. It has been shown that highly catalytic platinum electrodes improve the response time of YSZ sensors ${ }^{[4]}$.

Dimitrov and Dushkin ${ }^{[5]}$ studied the YSZ films incorporated with platimun nanospecies (Pt-YSZ) to detect oxygen and compared it with the behavior of pure YSZ thin films. They obtained that the $\mathrm{Pt}$ YSZ was stable for a much longer period of time than the YSZ sample and that regarding the transient conductivity of the $\mathrm{Pt}$-YSZ samples, the charge relaxed faster toward the equilibrium state than the pure YSZ samples.

In this study we have prepared YSZ sensors with Pt electrode films deposited by MOCVD to improve the efficiency and response time. Then, the present work was undertaken with the view to studying the efficiency of the YSZ sensors to estimate the oxygen content in $\mathrm{Cu}-\mathrm{O}-\mathrm{Mn}$ melts at 1,100, 1,200 and $1,300^{\circ} \mathrm{C}$. We have chosen manganese as deoxidizing agent because it interacts strongly with oxygen and produces remarkably changes in the oxygen potential in the melt.

\section{THERMODYNAMIC ANALYSIS}

Gómez et al. ${ }^{[6]}$ made a critical analysis of the deoxidation process of molten steel using the interaction parameter formalism for the thermodynamic of dilute solutions. They took into account the conventional deoxidation reaction of molten steel and the first-order interaction reaction.

The general deoxidation reaction of molten copper is written as:

$$
\mathrm{a} \underline{\mathrm{M}}+\mathrm{b} \underline{\mathrm{O}}=\mathrm{M}_{\mathrm{a}} \mathrm{O}_{\mathrm{b}}(\mathrm{s} \text { or I })
$$

where, $\underline{\mathrm{M}}$ and $\underline{\mathrm{O}}$ are the metal and oxygen dissolved in liquid copper. The equilibrium constant reaction (1) is given by:

$$
\mathrm{K}=\frac{a \mathrm{M}_{\mathrm{a}} \mathrm{O}_{\mathrm{b}}}{\left(\mathrm{h}_{\mathrm{M}}\right)^{\mathrm{a}}\left(\mathrm{h}_{\mathrm{O}}\right)^{\mathrm{b}}}
$$

$h_{M}$ and $h_{O}$ are the activities of metal and oxygen in liquid copper relative to dilute solutions of 1 weight percent standard state $(1 \mathrm{wt} \%) \cdot a \mathrm{M}_{\mathrm{a}} \mathrm{O}_{\mathrm{b}}$ is the activity of $\mathrm{M}_{\mathrm{a}} \mathrm{O}_{\mathrm{b}}$ relative to $\mathrm{M}_{\mathrm{a}} \mathrm{O}_{\mathrm{b}}$ pure as standard state. The values of $h_{M}$ and $h_{O}$ can be expressed by the following equations in terms of mass \% of metal and oxygen:

$$
\begin{aligned}
& \log \left(h_{M}\right)=\log (\% M)+e_{M}^{M}(\% M)+r_{M}^{M}(\% M)^{2}+e_{M}^{0}(\% 0)+r_{M}^{0}(\% 0)^{2} \\
& \log \left(h_{0}\right)=\log (\% 0)+e_{0}^{0}(\% 0)+r_{0}^{0}(\% 0)^{2}+e_{0}^{M}(\% M)+r_{0}^{M}(\% M)^{2}
\end{aligned}
$$

where, $\mathrm{e}_{\mathrm{M}}^{\mathrm{M}}, \mathrm{e}_{\mathrm{M}}^{\mathrm{O}}, \mathrm{e}_{\mathrm{O}}^{\mathrm{O}}$ and $\mathrm{e}_{\mathrm{O}}^{\mathrm{M}}$ are the first-order interaction parameters and $\mathrm{r}_{\mathrm{M}}^{\mathrm{M}}, \mathrm{r}_{\mathrm{M}}^{\mathrm{O}}, \mathrm{r}_{\mathrm{O}}^{\mathrm{O}}$ and $\mathrm{r}_{\mathrm{O}}^{\mathrm{M}}$ are the secondorder parameters. Combining the equations (2), (3) and (4), and assuming that the activity of $\mathrm{M}_{\mathrm{a}} \mathrm{O}_{\mathrm{b}}$ is unity, the following equation is obtained:

$$
\begin{aligned}
& \cdot \log (K)=a\left\{\log (\% M)+e_{M}^{M}(\% M)+r_{M}^{M}(\% M)^{2}+e_{M}^{0}(\% 0)+r_{M}^{0}(\% 0)^{2}\right\}+ \\
&+b\left\{\log (\% 0)+e_{0}^{0}(\% 0)+r_{0}^{0}(\% 0)^{2}+e_{0}^{M}(\% M)+r_{0}^{M}(\% M)^{2}\right\}
\end{aligned}
$$

This is a non linear equation where $\% \mathrm{O}$ can be estimated as function of $\% \mathrm{M}$. Plots of $\% \mathrm{O}$ in solution and in equilibrium with the oxide $\mathrm{MaOb}$ as a function of \% $\mathrm{M}$ generally show a minimum, that is, an optimum quantity of deoxidizer. The existence and the position of this minimum is easily found through the differentiation of equation (5) with respect to $\%$ M. At the minimum we have:

$$
\frac{\partial(\% \mathrm{O})}{\partial(\% \mathrm{M})}=0
$$

Consequently, a second order equation is obtained 
ANALYSIS OF THE DEOXIDATION PROCESS OF COPPER WITH MANGANESE USING A PLATINUM ELECTRODE-BASED SENSOR PREPARED BY MOCVD ANÁLISIS DEL PROCESO DE DESOXIDACIÓN DE COBRE CON MANGANESO USANDO SENSORES CON ELECTRODOS BASE PT PREPARADOS POR MOCVD

$$
(\% M)^{2}\left(2 a r_{M}^{M}+2 b r_{0}^{M}\right)+(\% M)\left(a e_{M}^{M}+b e_{0}^{M}\right)+a(0.434295)=0
$$

\section{EXPERIMENTAL PROCEDURE}

\subsection{Oxygen sensor}

YSZ sensors were prepared by blending $91 \mathrm{~g}$ of YSZ, $\mathrm{ZrO}_{2}-8 \% \mathrm{Y}_{2} \mathrm{O}_{3}$ (TOSOH®, TZ-8Y) with $50 \mathrm{~cm}^{3}$ of a solution of $0.01 \mathrm{M} \mathrm{NaNO}$ and $3.5 \mathrm{~cm}^{3}$ of ammonium polyacrylate as a dispersant. The body of the sensor was prepared by slip casting in a plaster of paris mold, followed by sintering in air at 1,873 $\mathrm{K}$ for $2 \mathrm{~h}$. The sensor was shaped in the form of a 5 $\mathrm{cm}$ long open-ended tube with an outside diameter of $8 \mathrm{~mm}$.

The YSZ tubes were coated over their entire surfaces with Pt electrode films using a horizontal hot-wall MOCVD apparatus, which has been described elsewhere ${ }^{[7]}$. The Pt films were carefully removed from the open edge of the tubes, using 400-grade emery paper, to form a working electrode on the external surface and a reference electrode on the internal surface of the tubes. Platinumacetylacetonate $\left[\left(\mathrm{CH}_{3}-\mathrm{COCHCO}-\mathrm{CH}_{3}\right)_{2} \mathrm{Pt}\right]$ was used as a precursor and its vapors were carried by an argon gas flow to the reactor chamber. Porous platinum films were obtained under the following deposition conditions: precursor temperature, $\mathrm{T}_{\text {prec }}=443 \mathrm{~K}$; deposition temperature, $\mathrm{T}_{\text {dep }}=673$ $\mathrm{K}$; total gas pressure, $\mathrm{P}_{\text {tot }}=133 \mathrm{~Pa}$.

The reference electrode was a mixture of $\mathrm{Ni}$ and $\mathrm{NiO}$, that has been found suitable for measurements at liquid copper temperatures ${ }^{[8]}$, encased in a stabilized zirconia electrolyte thimble. The YSZ oxygen sensor produces an EMF as a result of the difference in oxygen potential between the liquid copper and the reference electrode, which can be related to temperature using the Nernst equation:

$$
E M F=\frac{R T}{4 F} \ln \left[\frac{\mathrm{pO}_{2(\text { ref })}}{\mathrm{pO}_{2(\text { cooper })}}\right]
$$

where, $\mathrm{pO}_{2 \text { (ref) }}$ is the oxygen partial pressure established by the $\mathrm{Ni} / \mathrm{NiO}$ reference electrode, $\mathrm{pO}_{2 \text { (copper) }}$ is the oxygen partial pressure in equilibrium with oxygen in molten copper, $\mathrm{T}$ is the absolute temperature, $\mathrm{R}$ is the gas constant and $\mathrm{F}$ is the Faraday constant. With this type of electrode, the value of the oxygen potential at the copper/electrolyte interface is ill-defined because it involves oxygen transfer across the electrolyte wall to or from the reference electrode $\mathrm{Ni}-\mathrm{NiO}$. The Pt-film YSZbased sensor for detecting oxygen in copper is shown schematically in figure 1 .

The electrochemical properties of platinum electrode films on YSZ were investigated by impedance spectroscopy in the frequency range of $10^{5}-10^{-2} \mathrm{~Hz}$ using a Solartron 1255 frequencyresponse analyzer from 300 to $800^{\circ} \mathrm{C}$ in air. A Jeol 6300 scanning electron microscope with an accelerating voltage of $25 \mathrm{kV}$ was used to measure the particle size of the Pt film and its thickness.

The oxygen potential at the reference electrode, $\mathrm{pO}_{2}$ (ref), is established by the equilibrium reaction and the standard Gibbs free energy ${ }^{[9]}$ :

$$
\begin{gathered}
\mathrm{Ni}+1 / 2 \mathrm{O}_{2}(\mathrm{~g})=\mathrm{NiO} \\
\Delta \mathrm{G}_{\mathrm{Ni}}^{0}=\mathrm{RT} \ln \left(\mathrm{pO}_{2 \text { (ref })}^{1 / 2}\right)=-232187+83.165 \mathrm{~T}[\mathrm{~J}]
\end{gathered}
$$

In molten copper alloys, $\mathrm{pO} 2$ (copper) can be replaced by $\mathrm{hO}$, the oxygen activity in the 1 -wt $\%$ standard state, using the dissolution reaction of oxygen in molten copper and the Gibbs energy change ${ }^{[8]}$ :

$$
\begin{gathered}
1 / 2 \mathrm{O}_{2}=\underline{\mathrm{O}} \\
\Delta \mathrm{G}_{0}^{\circ}=-\mathrm{RT} \ln \left(\frac{\mathrm{h}_{0}}{\mathrm{pO}_{2(\text { copper })}^{1 / 2}}\right)=-74105+10.76 \mathrm{~T}[\mathrm{~J}]
\end{gathered}
$$

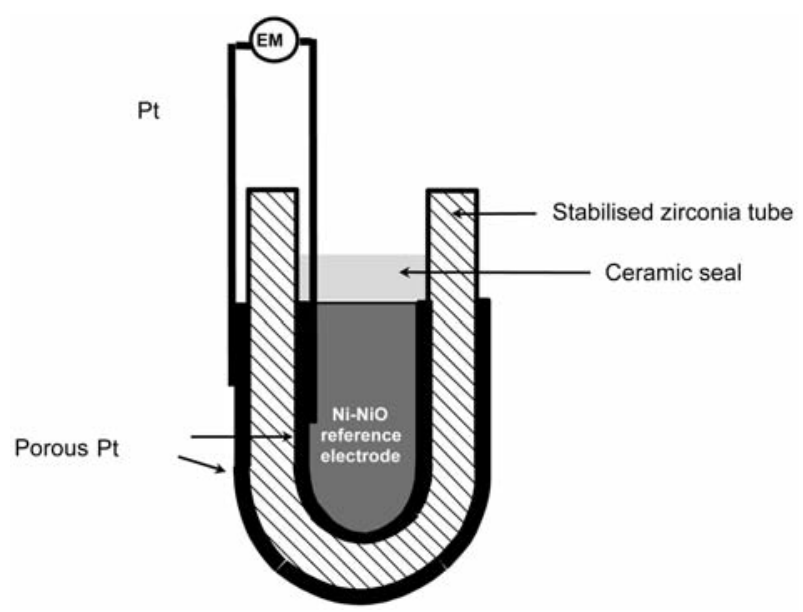

Figure 1. Cross-sectional view of YSZ-based sensor with Pt electrode films prepared by MOCVD.

Figura 1. Esquema de la sección transversal del sensor ZEI con electrodos de Pt preparados por MOCVD 
Combining equations (8), (10) and (12) the following expression for the oxygen activity is obtained:

$$
\log \left[h_{0}\right]=3.7822-\frac{8257.7+10080.3 E M F}{T}
$$

Finally, the oxygen content in molten copper is calculated combining the expressions (4) and (13)

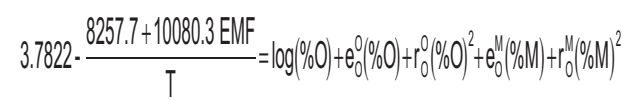

\subsection{Material, apparatus and procedure}

Experiments were carried out in order to study the effect of temperature, time and amount of manganese on the oxygen content of molten copper during the deoxidizing process. The temperatures tested were $1,100,1,200$ and $1,300^{\circ} \mathrm{C}$. The experimental process was carried out on $500 \mathrm{~g}$ of electrolytic copper (99.95\% purity). Copper was melted in high alumina crucibles in an open induction furnace. One addition of electrolytic manganese pellets ( $99.99 \%$ purity) was used in each experiment. The mass of manganese was 1,2 and $4 \mathrm{~g}(0.2,0.4$ and $0.8 \%$ of the mass of liquid copper, respectively). The size of manganese particles ranged from 1 to $2 \mathrm{~mm}$.

The melting temperature was measured with a R-type thermocouple ( $\mathrm{Pt}-\mathrm{Pt}, 13 \% \mathrm{Rh})$. After the required temperature was attained, the oxygen sensor was introduced into the liquid copper. When the EMF signal of the electrochemical cell was stabilized the initial metal sample was withdrawn into a small silica tube by suction and the predetermined amount of manganese was added to start the deoxidizing process. Subsequently, several metal samples were taken at 0.5, 1, 1.5, 2, 3, 4, 6 and $8 \mathrm{~min}$ to estimate the change in oxygen and manganese composition in the liquid copper. The manganese was analyzed by the atomic absorption method while the oxygen content was analyzed by an ELTRA ONH-2000 oxygen analyzer.

The working and reference electrodes of the oxygen sensor have $\mathrm{Pt}$ films with superior electrochemical performance to promote equilibrium in the cell. This enabled the determination of the level of oxygen potential based on the Nernstian response of the sensor. To check the reproducibility, some of the trials were carried out twice.

\section{RESULTS AND ANALYSIS}

\subsection{Platinum-film characterization}

A sample of the oxygen sensor was mounted and the microstructure was examined in detail by optical microscopy as well as SEM analysis. The SEM micrograph in figure 2 a) shows that $\mathrm{Pt}$ film prepared by chemical vapor deposition produced a particle size in the range of 100-200 nm. Figure $2 \mathrm{~b}$ ) shows a cross section of the platinum-film on the YSZ substrate. The depth of the Pt film measured by SEM analysis was about $7 \mu \mathrm{m}$.

Figure 3 shows the Arrhenius plot for the conductivity in relation to the total electrode resistance for Pt electrode films prepared by MOCVD on the YSZ substrate. The conductivity depends on

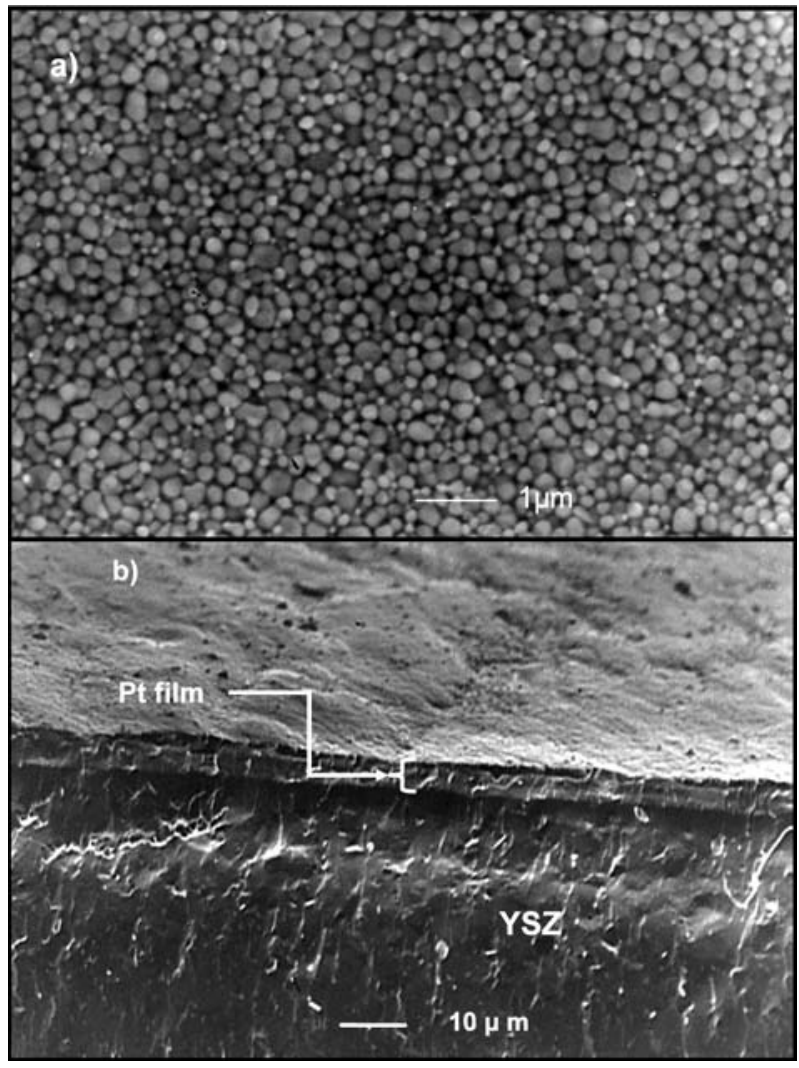

Figure 2. Micrograph produced by SEM of a Pt-film processed by MOCVD. (a) Platinum nanoparticles attached on the YSZ substrate; (b) Cross section of the platinum film.

Figure 2. Micrografía obtenida mediante MEB de la película de platino depositada por MOCVD. (a) Nanopartículas de platino depositadas sobre el sustrato de ZEl; (b) Corte transversal de la película de platino. 
ANALYSIS OF THE DEOXIDATION PROCESS OF COPPER WITH MANGANESE USING A PLATINUM ELECTRODE-BASED SENSOR PREPARED BY MOCVD ANÁLISIS DEL PROCESO DE DESOXIDACIÓN DE COBRE CON MANGANESO USANDO SENSORES CON ELECTRODOS BASE PT PREPARADOS POR MOCVD

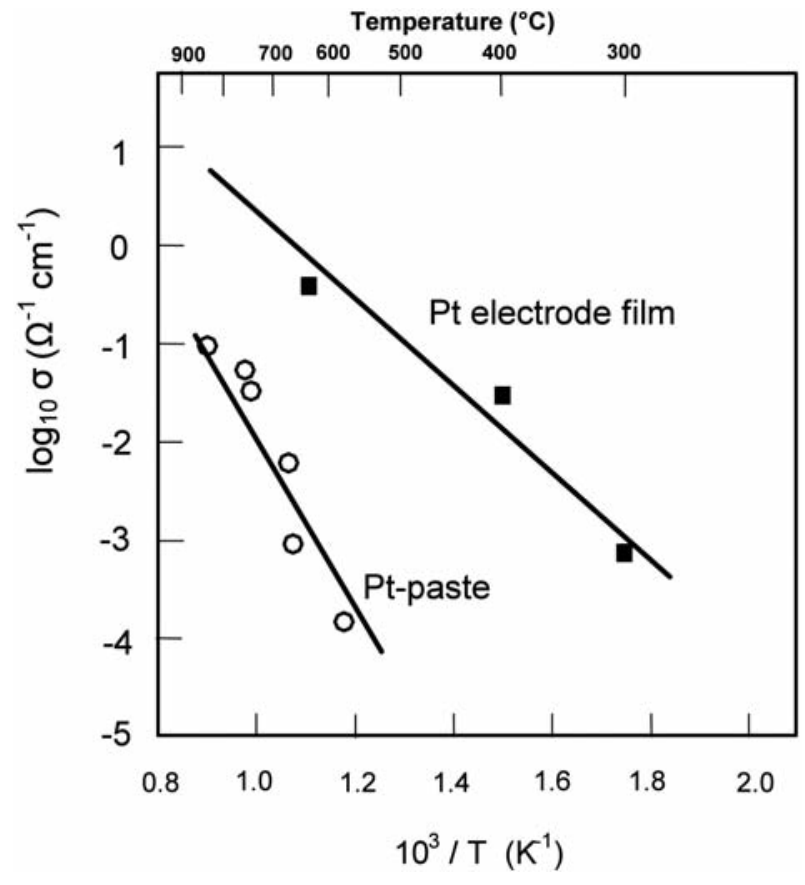

Figure 3. Arrhenius plots for the conductivity in relation to the total electrode resistance for MOCVD-Pt- and Pt-paste-based electrodes ${ }^{[10]}$.

Figura 3. Gráfica de Arrhenius para la conductividad en relación de la resistencia total del electrodo para los sistemas de platino depositado por MOCVD y de un electrodo de pasta de platino ${ }^{[10]}$. the physical dimensions of the electrode; in this work we prepared platinum films, about $7 \mu \mathrm{m}$ thick. The porous electrode structure on the YSZ surface is a region of three phases (oxygen-electrode-electrolyte) contact. The total electrode resistance is represented by the charge transfer component. Pt films exhibit a higher conductivity than conventional $\mathrm{Pt}$ paste electrodes at temperatures below $900^{\circ} \mathrm{C}^{[10]}$.

The sensor had a response time of about $2 \mathrm{~s}$. The fact that the response time was so short in the experiments was attributed to the Pt electrode films deposited on YSZ, which increased the electrode conductivity of the sensors compared with that of conventional YSZ sensors.

\subsection{Thermodynamic results}

The Gibbs free energy and the equilibrium constant of reaction (1) at $1,473 \mathrm{~K}\left(1,200^{\circ} \mathrm{C}\right)$ using as deoxidizer manganese, iron and phosphorus are given in table $\mathrm{I}^{[8,9,10-13]}$. The first and second order interaction parameters for the $\mathrm{Cu}-\mathrm{O}-\mathrm{Fe}, \mathrm{Cu}-\mathrm{O}-\mathrm{P}$ and $\mathrm{Cu}-\mathrm{O}-\mathrm{Mn}$ systems are given in table II ${ }^{[13-15]}$.

Figure 4 gives the oxygen solubility against the dissolved $\mathrm{M}(\mathrm{Mn}, \mathrm{Fe}$ and $\mathrm{P})$ at $1,473 \mathrm{~K}$ for the $\mathrm{Cu}$ $\mathrm{Mn}, \mathrm{Cu}-\mathrm{Fe}, \mathrm{Cu}-\mathrm{P}$ liquid systems. These results were calculated with the interaction parameters and the equilibrium constants given in tables I and II. There

Table I. Gibbs energy and equilibrium constant of the oxidation reactions in liquid copper

Tabla I. Energía de Gibbs y constante de equilibrio de las reacciones de oxidación en cobre líquido

\begin{tabular}{cccc}
\hline Reaction & $\Delta \mathbf{G}(\mathbf{J})$ & $\mathbf{K}_{\mathbf{1 2 0 0}}{ }^{\circ} \mathbf{C}$ & References \\
\hline $2 \underline{\mathrm{P}}+5 \underline{\mathrm{O}}=\mathrm{P}_{2} \mathrm{O}_{5}(\mathrm{I})$ & $-975,758+493.82 \mathrm{~T}$ & 642,045 & $8,11,12$ \\
$\underline{\mathrm{Fe}}+\underline{\mathrm{O}}=\mathrm{FeO}(\mathrm{s})$ & $-242,222+99.672 \mathrm{~T}$ & 2,417 & $8,9,13$ \\
$\underline{\mathrm{Mn}}+\underline{\mathrm{O}}=\mathrm{MnO}(\mathrm{s})$ & $-320,814+111.972 \mathrm{~T}$ & 337,207 & $8,9,13$ \\
\hline
\end{tabular}

Table II. Interaction parameters in Cu-O-M ternary alloys

Tabla II. Parámetros de interacción de aleaciones ternarias Cu-O-M

\begin{tabular}{cccccc}
\hline Element (M) & $\mathbf{e}_{\mathrm{O}}^{\mathbf{M}}$ & $\mathbf{e}_{\mathbf{M}}^{\mathrm{O}}$ & $\mathbf{r}_{\mathrm{O}}^{\mathrm{M}}$ & $\mathbf{r}_{\mathrm{O}}^{\mathrm{M}}$ & Reference \\
\hline $\mathrm{O}$ & $0.32844-683.93 / \mathrm{T}$ & $0.32844-683.93 / \mathrm{T}$ & $-0.01953+34.014 / \mathrm{T}$ & 0 & 14 \\
$\mathrm{Fe}$ & $10.788-19984 / \mathrm{T}$ & $37.679-69756 / \mathrm{T}$ & -0.0036125 & 0 & 13 \\
$\mathrm{P}$ & $3.4297-6244.2 / \mathrm{T}$ & $6.6346-12086 / \mathrm{T}$ & -0.043414 & 0 & 13 \\
$\mathrm{Mn}$ & $48.205-84354 / \mathrm{T}$ & $165.51-289650 / \mathrm{T}$ & 0 & 0 & 15 \\
\hline
\end{tabular}


ppm 0

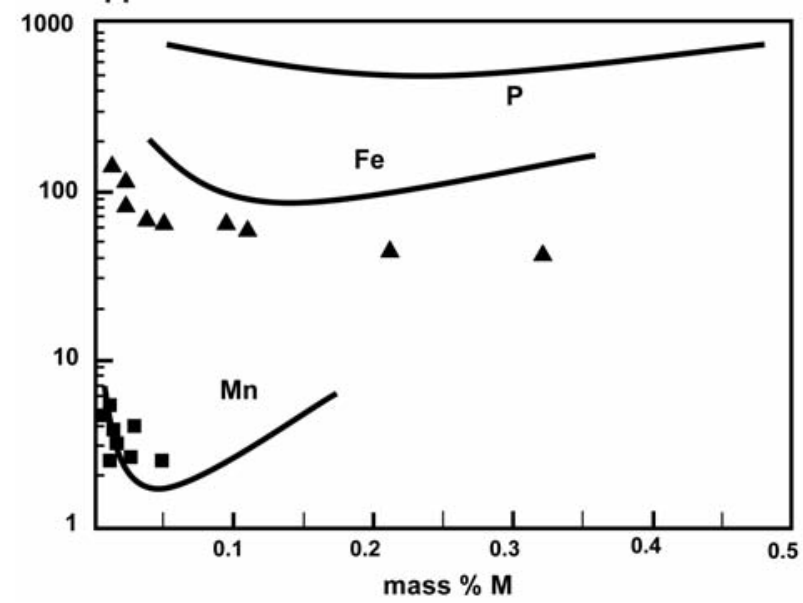

Figure 4. Solubility of oxygen in $\mathrm{Cu}-\mathrm{Mn}, \mathrm{Cu}-\mathrm{Fe}$ and $\mathrm{Cu}-\mathrm{P}$ melts in equilibrium at $1200{ }^{\circ} \mathrm{C}$. Experimental points: (?) Cu-Mnn ${ }^{15]}$; (?) $\mathrm{Cu}-\mathrm{Fe}^{[16]}$.

Figura 4. Solubilidad de oxígeno en los sistemas líquidos $\mathrm{Cu}-\mathrm{Mn}$, Cu-Fe y $\mathrm{Cu}-\mathrm{P}$ enequilibrio a $1200{ }^{\circ} \mathrm{C}$. Puntos experimentales: (?) $\mathrm{Cu}-\mathrm{Mn}^{[15]}$; (?) $\mathrm{Cu}-\mathrm{Fe}^{[16]}$.

exists a minimum in these systems even though the solubility curves are very shallow for the $\mathrm{Cu}-\mathrm{Fe}$ and $\mathrm{Cu}-\mathrm{P}$ alloys.

The minimum oxygen content strongly depends on the first-order interaction parameter $\left(\mathrm{e}_{\mathrm{O}}^{\mathrm{M}}\right)$. A deoxidizer has great affinity for oxygen and this results in an interaction coefficient $\mathrm{e}_{\mathrm{O}}^{\mathrm{M}}$ which is large and negative; in absolute values, it is generally much larger than $\mathrm{e}_{\mathrm{M}}^{\mathrm{M}}$. The interaction parameters for manganese, iron and phosphorus at $1,473 \mathrm{~K}$ are $\mathrm{e}_{\mathrm{O}}^{\mathrm{Mn}}=-9.062, \mathrm{e}_{\mathrm{O}}^{\mathrm{Fe}}=-2.779$ and $\mathrm{e}_{\mathrm{O}}^{\mathrm{P}}=-0.809$. Evidently, manganese reacts with oxygen more efficiently than iron and phosphorus.

Kulkarni ${ }^{[16]}$ reported that the lowest oxygen solubility in $\mathrm{Cu}-\mathrm{Fe}$ alloys was $22 \mathrm{ppm}$ oxygen at approximately 0.97 mass \% iron. This discrepancy can be explained because $\mathrm{FeO}$ is considered in the thermodynamic calculations as the only oxidation product whereas Kulkarni considered a mixture of $\mathrm{FeO}$ and $\mathrm{Fe} 3 \mathrm{O} 4$. There exits a good agreement between the experimental ${ }^{[15]}$ and the calculated results for the $\mathrm{Cu}-\mathrm{Mn}$ system.

\subsection{Experimental results}

Figure 5 shows the variation of manganese content in the copper after the deoxidizing treatment using $0.2,0.4$ and 0.8 mass $\%$ manganese at $1,200^{\circ} \mathrm{C}$. It is clear that higher amounts of manganese will promote

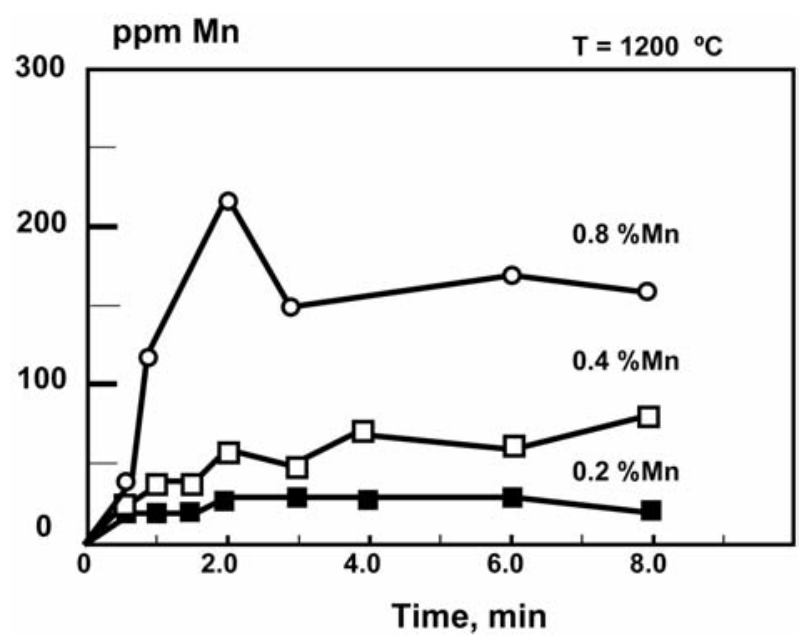

Figure 5. Manganese content in terms of time of process and initial mass $\%$ manganese at $1,200{ }^{\circ} \mathrm{C}$.

Figura 5. Contenido de manganeso en términos del tiempo de proceso y del \% masa de manganeso inicial a $1.200^{\circ} \mathrm{C}$.

higher residual manganese in the molten copper; even though, most of the manganese reacts with the dissolved oxygen, according to reaction (1).

The oxygen partial pressure in the liquid copper, $\mathrm{pO}_{2 \text { (copper) }}$, is calculated from the EMF values, according to equation (8) and using the value for $\Delta \mathrm{G}_{\mathrm{Ni}}^{\mathrm{o}}$ given in equation (10). The oxygen activity, $\mathrm{hO}$, is estimated with equation (4) using the experimental oxygen and manganese contents. Then, the value of $\mathrm{pO}_{2 \text { (copper) }}$ can also be calculated using equation (12). Figure 6 shows the effects of temperature and the reaction time on the $\mathrm{pO}_{2 \text { (copper) }}$ in the liquid copper with 0.2 mass \% initial manganese content. $\mathrm{pO} 2 \mathrm{emf}$ represents the results obtained with the Nernst equation and $\mathrm{pO}_{2}$ c.a. represents the values calculated through the interaction parameters and the oxygen and manganese contents.

Figure 6 shows that there exists good agreement between the $\mathrm{pO}_{2}$ emf and $\mathrm{pO}_{2}$ c.a. at 1,200 and $1,300{ }^{\circ} \mathrm{C}$, but they differ at $1,100^{\circ} \mathrm{C}$. This may be probably attributed to the fact that the diffusion of the oxygen ions through the solid electrolyte is more efficient at higher temperatures, and that the interaction parameters for the $\mathrm{Cu}-\mathrm{Mn}-\mathrm{O}$ at 1,100 ${ }^{\circ} \mathrm{C}$ has been extrapolated from experimental parameters obtained at 1,200 and $1,300^{\circ} \mathrm{C}^{[15]}$.

Oxygen contents can be calculated by combining the measured probe EMF and the manganese content with the interaction parameters of the $\mathrm{Cu}-\mathrm{O}-\mathrm{Mn}$ system in equation (14). The oxygen levels measured 
ANALYSIS OF THE DEOXIDATION PROCESS OF COPPER WITH MANGANESE USING A PLATINUM ELECTRODE-BASED SENSOR PREPARED BY MOCVD ANÁLISIS DEL PROCESO DE DESOXIDACIÓN DE COBRE CON MANGANESO USANDO SENSORES CON ELECTRODOS BASE PT PREPARADOS POR MOCVD

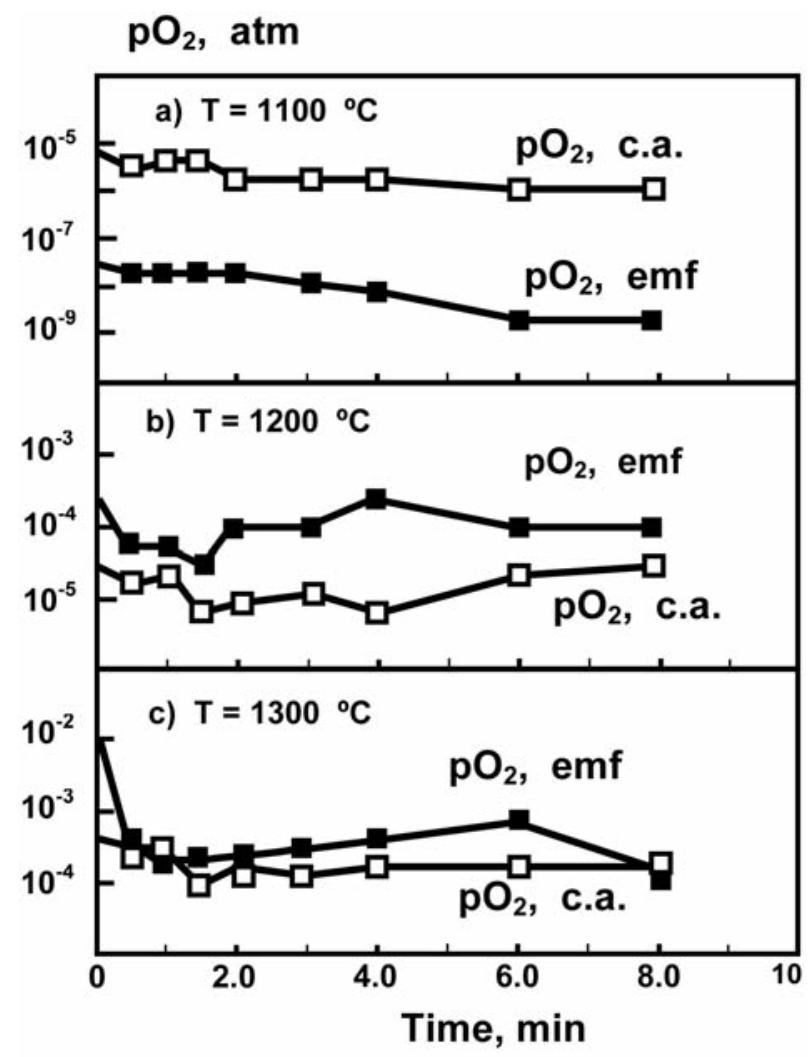

Figure 6. Oxygen partial pressure in terms of time of treatment. $\mathrm{pO}_{2}$ emf is calculatedthrough the Nernst equation; $\mathrm{pO}_{2} \mathrm{c}$.a. is estimated through the oxygen and manganese contents and the interaction parameters.

Figura 6. Presión parcial de oxígeno en términos del tiempo de tratamiento. $\mathrm{pO}_{2}$ emfes calculado mediante la ecuación de Nernst; $\mathrm{pO}_{2}$ c.a. es estimado mediantelos contenidos de oxígeno y manganeso y los parámetros de interacción.

by the probe as well as those obtained by chemical analysis for the trials with $0.4 \%$ manganese at 1,100 to $1300{ }^{\circ} \mathrm{C}$ are shown in figure 7 . Good agreement was obtained between calculated and experimental results, although a strict comparison gives some discrepancy. The deviation in the calculated results, especially at $1,100^{\circ} \mathrm{C}$, can be a consequence of both the interaction parameter $\left(\mathrm{e}_{\mathrm{O}}^{\mathrm{Mn}}\right)$, which is reported to be valid at 1,200 and $1,300{ }^{\circ} \mathrm{C}^{[15]}$, and the high oxygen concentration, where the interaction parameters model becomes less accurate.

Evidently, the system is not in equilibrium and the oxygen solubility obtained in this work are lower than the following values reported by Schmid ${ }^{[17]}$ : 0.56 mass $\%$ oxygen at $1,100{ }^{\circ} \mathrm{C}, 2.16 \%$ oxygen at mass $\% 0$

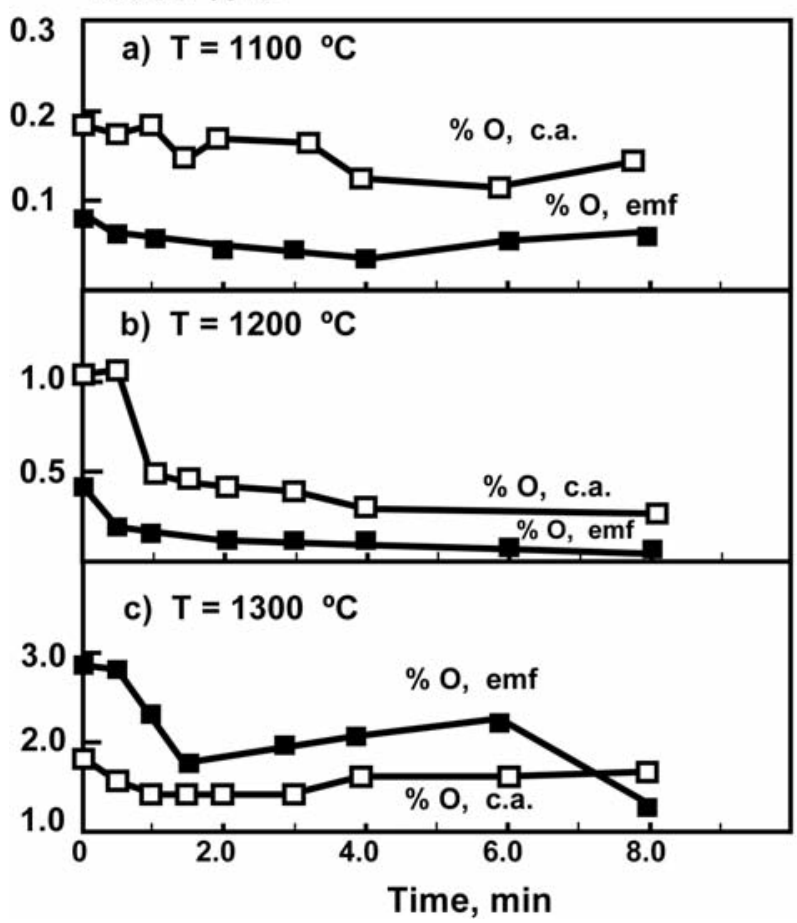

Figure 7. Oxygen solubility in terms of temperature and time of treatment. \% oxygen emf is calculated through the Nernst equation; $\%$ oxygen c.a. is obtained by chemical analysis.

Figura 7. Solubilidad de oxígeno en términos de la temperatura y el tiempo de tratamiento. \% oxígeno emf es calculado mediante la ecuación de Nernst; \% oxígeno c.a. es obtenido mediante análisis químico.

$1,200^{\circ} \mathrm{C}$ and $4.25 \%$ oxygen at $1,300^{\circ} \mathrm{C}$. Even though the system is not in equilibrium, the oxygen probe with Pt electrode films can be a useful process control tool in the casting of copper to estimate the required deoxidizing agent needed to reach a given oxygen level in the system at a fixed temperature.

\section{CONCLUSIONS}

A sensor employing yttria-stabilized zirconia with Pt electrode film was used to determine the oxygen content in liquid $\mathrm{Cu}-\mathrm{Mn}$ alloys from $1,100^{\circ}$ to $1,300^{\circ} \mathrm{C}$. The oxygen partial pressures estimated with the sensor were in agreement with the theoretical values. For example, in the deoxidation test with $2 \mathrm{~g}$ manganese, the $\mathrm{pO}_{2}$ at $1,100^{\circ} \mathrm{C}$ was between $10^{-7}$ and $10^{-8} \mathrm{~atm}$, at $1,200^{\circ} \mathrm{C}$ was from $10^{-7}$ to $10^{-5}$ atm and at $1,300^{\circ} \mathrm{C}$ was between $10^{-5}$ and $10^{-3} \mathrm{~atm}$. This is in agreement with the fact 
that the higher the temperature the higher the solubility of oxygen in the molten copper.

The EMF obtained with the sensor enabled the estimation of the oxygen contents, which were close to the values obtained by chemical analysis at $1,200^{\circ}$ and $1,300^{\circ} \mathrm{C}$. However, at $1,100^{\circ} \mathrm{C}$ there was obtained a poor agreement. The deviation in the calculated results can be a consequence of the lack of a reliable value of the interaction parameter $\left(\mathrm{e}_{\mathrm{O}}^{\mathrm{Mn}}\right)$.

The interaction parameters model was used to estimate the equilibrium oxygen content in the liquid $\mathrm{Cu}-\mathrm{Mn}, \mathrm{Cu}-\mathrm{Fe}$ and $\mathrm{Cu}-\mathrm{P}$ systems. The thermodynamic analysis showed that the minimum oxygen content at $1,200^{\circ} \mathrm{C}$ was about $2 \mathrm{ppm}, 90$ ppm and 500 ppm using manganese, iron and phosphorus as deoxidation agents, respectively.

\section{Acknowledgements}

The authors wish to thank the institutions CONACyT, SNI, COFAA and Instituto Politecnico Nacional for their permanent assistance of the Process Metallurgy Group at the ESIQIE Metallurgy and Materials Department.

\section{REFERENCES}

[1] R. Ramammoorthy, P. Dutta and S.A. Akbar, J. Materials Sci. 38 (2003), 4.271-4.282.

[2] N. Miura, G. Lu and N. Yamazoe, J. Electrochem. Soc. 143 (1996) 609-613.

[3] I. Natali-Sora, C. Schmid and C.M. Mori, Proc. $17^{\text {th }}$ Riso Int. Symposium Materials Science: High
Temperature Electrochemistry: Ceramics and Metals, Riso National Laboratory, Roskilde, Denmark, 1996, pp. 369-375.

[4] A. Sharma and P.D. Pacey, J. Electrochem. Soc. 140 (1993) 2.302-2.309.

[5] D. T. Dimitrov and C. D. Dushkin, Central European J. Chem. 3 (2005) 605-621.

[6] P. Gómez, F. Reyes, J. Gutiérrez and G. Plascencia. Rev. Metal. Madrid, 45 (2009) 305-316.

[7] A. Hernández, A. Romero-Serrano and F. Chávez, ISIJ Int. 38 (1998) 126-131.

[8] S. Seetheraman, D. Sichen and A. Jakobsson, Proc. Symp. Application of Sensors and Modeling to Materials Processing 1997, Orlando, Florida, EE. UU., 1997, pp.327-345.

[9] I. Barín, Thermochemical Data of Pure Substances, VCH Verlagsgesellschaft, Germany, (1989).

[10] S.P.S. Badwal and H.J. de Bruin, Phys. Stat. Sol. 54 (1979) 261-272.

[11] D.R. Stull and H. Prophet, JANAF Thermochemical Tables, U.S. Department of Commerce, Washington (1985).

[12] M. Iwase, E. Ichise and N. Yamada, Steel Res. (1985) 319-326.

[13] G.K. Sigworth and J.F. Elliot, Can. Met. Q. 13 (1974) 455-461.

[14] R. Schmid, Metall. Trans B, 14 (1983) 473-481.

[15] S. Seetheraman, K. Abraham and L. Staffansson, Scand. J. Metall. 7 (1978) 176-180.

[16] A.D. Kulkarni, Metall. Trans, 4 (1973) 1.713. 1.721.

[17] R. Schmid, Metall. Trans. B, 14 (1983) 473. 481. 